\title{
The Ideological Recomposition of Political Elites in Serbia since 2012
}

\author{
LAURENT TOURNOIS
}

\section{Sciendo}

Politics in Central Europe (ISSN: 1801-3422)

Vol. 17, No. 3

DOI: $10.2478 /$ pce-2021-0025

\begin{abstract}
This article argues that the ideological recomposition that has followed Aleksandar Vučićs first tenure in 2012 has blurred the lines between the various political ideologies Serbia has been associated with over the past 30 years, from nationalism to conservatism, populism, hybridity and, ultimately, authoritarianism. Using discursive analysis, the political strategy and narrative schemes examined therein illustrate the inherent tensions of 'conservatism' as practiced by Serbia's political elite. This article also develops a minimal explanation of the results and consequences of the political developments that have taken place from 2012 to 2020. It highlights the dynamic discursive construction/deconstruction of the ruling party's ideology which has not been considered in existing scholarly studies on the categorisation of contemporary Serbia's political regimes. Finally, by investigating the symbolic and emotional dimensions of the ideological recomposition ongoing in Serbia (i.e. the cultural trauma that followed the dissolution of Yugoslavia, heteronomy and ontological (in)security), this article contributes to the literature on growing political changes occurring in post-communist societies.
\end{abstract}

Keywords: conservatism; nationalism; ideological recomposition; democratization; Serbia; Aleksandar Vučić

Since the late 1990s and during the 2000s, it has become clear that the success of conservative parties was not an electoral accident in post-communist countries. Moreover, during the 2010s, academics and political experts increasingly insisted on the rise of nationalism. For their part, the political elites in power in Serbia since 2012, under the leadership of Aleksandar Vučić ${ }^{1}$ and his party

1 In this paper, the terms 'Aleksandar Vučić', 'ruling party', 'political elite', 'ruling elite', 'government' and 'political establishment' are considered synonymous. 
the Srpska Napredna Stranka or Serbian Progressive Party (SNS), affirmed their desire to transform the country and bring it closer to European Union (EU) standards, particularly on the issue of LGBT rights, democracy and Kosovo. In a context of weak political competition in the sense of Roemer (see Roemer 2001), ${ }^{2}$ the ideological recomposition that followed, however, blurred the lines between the various ideologies that have marked the historical course of the country since the end of the Yugoslav experience.

In this paper, I first examine how the dominant party (SNS) literally 'machines' conservative ideas into its political offer (for example, the (denial of) LGBT, Roma and migrants' rights, which are (were?) usually the 'business' of conservative/ far-right movements, have gradually become an integral part of the country's EU integration process), whether it concerns speeches geared towards its supporters, to non-party voters or to EU officials and other international actors. In other words, I seek to improve the understanding of the strategies implemented by the ruling party since 2012, that is to say, in 'what ways' and under what conditions. For example, it is about questioning the strategy aiming at 'demobilizing' or 'demonizing' the internal challengers (Gagnon 2004) in resolving the various challenges Serbia faces, such as the Kosovo issue and the country's EU integration process, which has not (yet) received massive support from the population as evidenced by the results of the June 2020 parliamentary elections.

To do so, I use 'discursive analysis' or an 'interpretive approach to public action' (see for example, Yanow, 2007) applied to the policy implemented by the government of Aleksandar Vučić since 2012. Assuming that politics are about processes that entail 'persuasion' and 'haggling' (Miller 1991), media play a key role in carrying the language of the political elite (Chilton 2004). In the first round, I screened newspaper articles from Politika (close to the ruling party) and Danas (in opposition to the ruling party) ${ }^{3}$ spanning from 2006 to 2021. Articles were selected on the basis of several keywords which combined Aleksandar Vučić and LGBT, migrants, Kosovo and opposition. Then, in the second round, the body of material was extended to pieces published by nine online newspapers including Deutsche Welle (DW), Al Jazeera Balkans, BalkanInsight, Beta, AP News, Slobodna Evropa, N1, Nova Ekonomija and Blic. Finally, sources from Istinomer, an online fact-checking portal, as well as TV news and broadcasted interviews (on YouTube) were added ${ }^{4}$.

2 The initial assumption underlying the political competition model proposed by Roemer (2001) is that political parties play no role. Among the characteristics of political competition in developing countries that La Ferrara and Bates (2001) detailed, two seem interesting to me because they potentially reflect the situation in Serbia: weak democratic institutions and 'personalist' policies, i.e. based on leader's charisma.

3 It should be noted that a large number of articles published by Danas are adapted from articles already published in foreign media (BBC News in Serbian, Al Jazeera).

4 Discursive analysis was based on a broad body of material that was formed for the sake of a larger research project which also explores the resistance to Europeanisation (in Serbia) and practices and effects of political competition in the Balkans. 
In line with an interpretivist posture, my field work uses an ethnographic method as well. Following the contention of Wedeen (2010), an ethnographic method serves to establish causal explanations and thus can help ground the political strategy(ies) of the Serbian ruling party from 2012 to 2020 and to what extent it pervades the micro-level. It entails an immersive approach, that is to say participant observation and informal interviews 5 , into the everyday lives of the inhabitants of Serbia, whether in Belgrade the capital city or in smaller towns. In addition, while a political scientist standing outside the ruling regime, I was involved with the (almost) continuously changing Serbian political landscape with the aim of being 'totally open to the setting and subjects of their/my study' (Gorman - Clayton, 1997: 38). It means regularly attending and taking personal notes during and after political meetings and protests. On the other hand, the research methods I use are designed to more scientifically analyse the political strategy of the ruling party but 'without any ambition to transform it'.

Accordingly, I explore the explanatory factors of the almost constant process of ideological recomposition of the ruling party and partisan systems through three structuring angles: the cultural trauma that followed the dissolution of Yugoslavia, heteronomy and ontological (in) security. In this regard, I argue that the reorganisation of the local political space is guided in part by a feeling of 'ontological insecurity' which is rooted in the 'cultural trauma' following the bombings of Belgrade/Yugoslavia in 1999 (see Racz 2009). The idea is also to debate the prevailing view that the needs for security and certainty organically lead to a broad right-wing ideology (see Malka et al., 2014) in an 'ideologically constrained country in transition'. To the best of my knowledge, these symbolic and emotional geographies have not yet been considered in existing studies on contemporary Serbia.

The remainder of this paper is organised as follows. I first address the categorisation issue from both a theoretical and practical standpoint with an emphasis on the most recent advances in the relevant scholarly literature in various post-communist settings. Next, the research context is briefly presented with a particular focus on the backdrop of Aleksandar Vučić's political career aiming to theoretically ground it. I also draw on the argument developed by Komel (2019) that political impetuses resist rationalisation, which renders them difficult to examine critically, to suggest that psychological processes/emotions have to be taken into account, principally in tackling certain aspects of state's foreign policy. Then, the discussion is broken into four significant periods which aims to provide a sequenced understanding of the ideological recomposition of the political elite along with internal and external events during the 2012-2020

5 Given the public's sensitivity to topics such as nationalism, party voting and, broadly speaking, a widespread feeling of being 'secretly watched' by government entities, a phenomenon Svenonius and Bjorklund (2018) named 'ontological insecurity', interviews were conducted in an informal manner. 
timeframe. The analysis challenges the prevailing view and underlines the necessity to go beyond a fixed classification in analysing the political strategy of the ruling party. Finally, I speculate on the possible consequences of the current government's discourse (swing). The narrative scheme put in place has consisted of using right-wing extremism and the conservative ideas it carries as a political instrument (in other words, a 'scarecrow') in a comparative perspective directed towards the EU and other international players. This shift, which has left a vacant space, is also a double-edged sword: the so-called 'traditional' opposition has almost completely disappeared from the landscape, leaving political space in Serbia to parties from ethnic minorities (Hungarians, Bosnians, Albanians, Croats) and to current government satellites.

\section{A problem of categorisation}

Categorising political regimes after the fall of the Berlin Wall has been challenging for political analysists and scholars alike. Backed by a set of 141 countries spanning from 1950 to 1990 , Alvarez et al. (1996) proposed classifying political regimes as democracies and dictatorships or authoritarian regimes. Covering a wider period (1800-2016), Anckar and Fredriksson (2019) went further and decomposed democracies (republics and monarchies) and autocracies (absolute monarchy, military rule, party-based rule, personalist rule and oligarchy) into several categories and sub-categories.

With regard to post-communist countries specifically, over the past decade, scholars have underlined various trends, from global patterns of an updated version of 'competitive authoritarianism (Levitsky - Way 2010; Bieber 2018a) to 'situational nationalism' in Montenegro (Jenne - Bieber 2014), 'illiberalism/illiberal democracy' in Hungary (Kürti 2020) and Poland (Karolewski 2020), 'conservatism' in Slovakia (Sekerák 2019) and, broadly speaking, 'de-democratization' (Szymański - Ufel 2018; Procházka - Cabada 2020). The common denominator of these regimes is democratic backsliding which is rooted in the failure of reformist governments in forming independent and democratic institutions since the beginning of the 2000s.

Retrospectively, political conservatism, populism, right-wing extremism and/or nationalism are themes with which the political landscape of Serbia is often associated. The politics of Serbian government since Aleksandar Vučić's first tenure as prime minister in 2012 could be viewed through multiple lenses. Zulianello (2020) categorised his party, the SNS, as 'right-wing/national-conservative' within populist parties. I aim to show that the SNS pushed or blurred the boundaries between the various classifications thanks to, for instance, the number of development projects and reforms his government implemented from 2012 to 2019 in order to redesign Serbia's national project. For instance, the legal improvements and discourses about LGBT/minorities 
and migrants' rights, depict him as 'cosmopolitan', 'embracing diversity and welcoming immigration', 'often turning those topics into litmus tests for moral respectability' (Haidt 2016: 47), thus 'erasing' ethnonationalist associations to Serbia, leaving racism to right-wing movements. Furthermore, this study intends to illustrate that, after the country's democratic experience in the 2000s, it has evolved towards a form of illiberal or hybrid democracy, reminding us of what the American diplomat Richard Holbrooke said in 1996: 'Democratically elected regimes, often ones that have been reelected or reaffirmed through referenda, are routinely ignoring constitutional limits on their power and depriving their citizens of basic rights and freedoms' (Zakaria 1997: 22).

Although or because populism is such a popular phenomenon, scholars have regularly emphasised its contested nature during the past 50 years (e.g. Gellner - Ionescu 1969; Mudde - Kaltwasser 2013). In order to capture its very nature, Moffitt and Tormey (2014: 387) have proposed conceptualising populism as a 'political style' that is 'the repertoires of performance that are used to create political relations'. As such, it may act as a header to various political styles such as authoritarianism. Specifically, populist politics concentrate power struggles and emotional contexts as well as to (for) whom and against whom they are addressed and include fundamental existential parameters such as 'ontological security' (Steele - Homolar, 2019). On the one hand, applying this line of reasoning to Serbia under the SNS rule means that 'modern' Serbs oppose those who reject change. On the other hand, as I will show, the political strategy and supporting state narratives are truly 'boundary-making' with respect to Serbian opposition from moderates to extremes but are not with regard to xenophobic-based exclusion. Moreover, I argue that the emotionally charged processes here in place are related to both an individual's 'security as being' and 'security of survival' (see Giddens 1991).

Scholars have highlighted that today's nationalism significantly differs from its predecessors. In the Western world, it has evolved towards a more defensive position, from the belief in an ancestral cultural superiority of one's own nation to egalitarianism, justice and the right to have different arguments (Milisavljević 2019). It is this updated nationalist stance that has allowed a certain normalisation of the ruling party in the Serbian political landscape.

Mapping out the features of (political) conservatism as practiced by Serbia's ruling party is a challenging task given the ambivalent and/or contradictory nature of certain decisions taken during a period of changing narratives regarding 'open immigration' and smoothing of 'identity politics'. As a political ideology, I adhere to the view of Allen (1981) for whom conservatism can't be defined mainly in terms of a straightforward attitude towards change. Indeed, it is widely accepted among scholars that 'conservatives have been willing to accommodate and even promote some forms of change, if only to strengthen the overall framework of society' (Allen 1981: 583). When scrutinising the politics 
of Aleksandar Vučić since 2012, I highlight their contradictions which illustrate the view of Alexander (2013: 596): 'It is against change; and yet it accepts change. It is against ideology; and yet it is an ideology. It is against reaction; and yet it involves reaction. It advocates no ideals; and yet it advocates ideals. It is secular; but it is religious. It is in favor of tradition; but there is nothing in it which prevents it from eventually abandoning any tradition'.

Kapidžić (2020: 2) provides a highly pragmatic approach to illiberal politics as the 'sets of policies that extend an electoral advantage for governing parties with the aim to remain in power indefinitely'. As such, it converges with conservatism. Following this line of reasoning, and through the governing practices that consist in engaging 'targeted restrictive actions against political opponents' (particularly in the media sphere), I call to attention the growing intensity of illiberal politics and authoritarian trajectory of Serbia and its consequences in terms of democracy.

When it comes to the Kosovo ${ }^{6}$ and, broadly speaking, territoriality issues, the politics conducted by Aleksandar Vučić could be characterised as 'populist' according to the definition outlined by Fukuyama (2018: 1): it is a policy that is 'popular in the short term but unsustainable in the long run'; such policy aims to please a 'certain ethnic or racial group' and/or at least recall nationalist sentiments within certain segments of the population; it emphasises the 'cult of personality' Aleksandar Vučić has developed around himself in order to 'develop an immediate relationship with the "people"' he claims to represent. Moreover, as the narratives revolving around the Serbia-Kosovo dialogue may show, states may not intend to avoid dilemmatic dispute because even risky routines offer ontological security (Mitzen 2006). 'Regional stability' will progressively appear as one of the major outcomes of such security-seeking foreign policy. The underlying issue then would be how long a rational stance could be maintained over an emotional conflict.

While scholars seem to agree to categorise the Serbian political regime as a 'hybrid', they also emphasise its continuous evolution towards a 'more radical version of electoral authoritarianism' (Pavlović 2020). However, Serbian reality challenges the theoretical argument that hybrid regimes facilitate popular dissent by providing significant institutional resources to opposition parties to organise and confront the regime in power, as well as grievances that strongly stimulate popular distrust (Vladisavljević 2016). The latter stance implicitly neglects the structural weaknesses of the opposition and underestimates the negative effects of the strategy of 'destabilizing' internal challengers. Thus, at least in the short run, such politics may simply strengthen the interests and capacities of Serbia's political establishment at the expense of opposition forces. Contrary to what happened in Serbia under Slobodan Milošević's rule, which

6 Understood as the 'recognition or not' of the independence of the former Serbian province. 
experienced a massive opposition protest campaign in 2000, they are able to prevent any regime change.

Given the preceding debate, I endorse the view of Kapidžić (2020) about the limitations of a fixed regime classification and, hence, I adopt a 'back-and-forth' perspective to dynamically look into the gradual evolution of the governing practices of the ruling party that dominated the political life of Serbia from 2012 to 2020. Accordingly, I 'keep the door open' in examining the sets of strategies and discursive practices implemented by Aleksandar Vučic's ruling elite. That is to finally suggest that the ideological background of Aleksandar Vučić's politics is a blend. By 'conservative resistance', I mean resistance to the return of ethnonationalist tendencies and, broadly speaking, facing the consequences of the legacies of the dislocation of Yugoslavia, with all the contradictions that it implies.

\section{Aleksandar Vučić both a product of a context and an influencing factor}

As a foreword, Aleksandar Vučić has recently felt into the spotlight of academic research as part of those local figures that 'have been shaped by the era [1990s], only to shape coming eras, as they continued to rise to new heights in the decades to come' (Jovanović 2019: 61).

Aleksandar Vučić entered into politics during the break-down of Yugoslavia. Indeed, he joined the Srpska Radikalna Stranka (SRS, Serbian Radical Party) in 1993. Then, he was elected as member of the National Assembly of the Republic of Serbia with an almost student status but as a 'radical'. Two years later, he became SRS general secretary. During this period of less than two years, three consecutive parliamentary elections in multiparty Serbia took place. Above all, Socijalistička partija Srbije (SPS) or the Socialist Party of Serbia split from the SRS in the summer of 1993 after that Slobodan Milošević's party had abandoned its harsh national policy, which had until then been advocated by the SPS (Kojić 2020). One may assume that this experience left an important mark and was able to condition his attitude not only towards his coalition partners but also on the necessary cohesion on key themes and, finally, on the use of elections as a mechanism of (re)construction of legitimacy.

When the SRS formed a government coalition (notably with the SPS) on 24 March 1998 in the midst of the Kosovo crisis, Aleksandar Vučić was elected minister of information. During his ministerial tenure, he signed the Public Information Law, and is remembered for his draconian media punishments, which led to the shutdown of foreign and local newsrooms opposed to the government. Today, when accused of interfering with the work of the media, he replies that 'it is easier to attribute this to him when there are no other arguments against him ${ }^{7}$.

7 https://www.istinomer.rs/akter/aleksandar-Vučic/. 
The situation in Serbia in 2012 offered the SNS fertile ground, bringing together disappointed voters, transition losers, a declining standard of living after the improvement observed at the end of the 2000s and a slow European integration among other complaints. In addition, the political landscape that emerged in Serbia after the 2007/2008 elections was characterised by a high degree of citizens' distrust in politics and a low perception of the state of democracy, which has fostered the emergence of new actors likely to ride the populist wave (Stojiljković - Spasojević 2018). Thus, thanks to a weakly institutionalised party system and an unconsolidated democracy, Serbia held/holds the structural conditions for highly influential leaders to be able to significantly (re)shape the society and its politics (Spasojević 2020). Interestingly, the SNS roadmap will gradually draw inspiration from the program of the Demokratska Stranka (DS) or Democratic Party which lost the 2012 elections, namely a pro-European approach, the strengthening of democratic standards, the stability of the exchange rate, food price control and macroeconomic balance (Orlović 2011).

Attitudes towards Serbian opposition occupy a particular place in the political strategy of Aleksandar Vučić, alongside Slobodan Milošević's systematic destruction of alternative centers of power. The book written by Eric Gordy Culture of power in Serbia: Nationalism and the destruction of alternatives in 2010 could have been his bedside book. This is to suggest the adoption of a more constructivist stance which would allow it to be seen as a 'framing' strategy, directed particularly towards Serbian extremist groups (see Valtner 2021). Moreover, while the political landscape between 2008 and 2012 showed relative political stability, the ideological recomposition, which constitutes the other pillar of its policy, consisted of an intentional contraction of the ideological space and a 'cartelization' of the party structure (Spasojević 2019).

Moreover, one may assume that he learned from the political career of Vojislav Kostunica. Firstly, the latter is the portrait of the kind of opponent he should fear as he is 'the man who overthrew Milošević' (see Budding 2002). He also enjoys the flattering reputation of being 'the opposition's only uncorrupted tenor'8. Secondly, while a democrat, his nationalist rhetoric (he was opposed to the extradition of Slobodan Milošević to the International Criminal Tribunal for the former Yugoslavia) contributed to the deterioration of the country's already fragile economy with the local currency losing six percent of its value in early 2008 (Barlovac 2010).

The elements presented so far lead me to propose that the 'theory of state collapse' may constitute the original backdrop of Aleksandar Vučić's politics as he witnessed the dissolution of both Yugoslavia (1992) and the Federal Republic

8 Lawyer and political scientist, born in 1944 in the small village of Kostunica, in Šumadja, Vojislav Kostunica can also boast of a prominent political coherence, marked with the seal of moderate nationalism (Dérens - Samary 2000). 
of Yugoslavia also known as 'Serbia and Montenegro' (2006). Therefore, it is possible to hypothesise that a number of psychological processes are at work here at both the state and individual levels. In order to benefit from first-hand feedback, I asked several individuals that lived through the bombing of Belgrade, whether hiding in the basements, singing in one of the city's squares or silently protesting on a Belgrade bridge 'Why do you vote for him [Aleksandar Vučić]?'9 One of them, K. (a Belgradian woman aged 82), replied: 'It doesn't matter for whom, just they (NATO) don't bomb us (again)'. Such verbatim illustrates the prevailing theoretical view that ontological security is rooted in the existentialist literature on anxiety (see Gustafsson - Krickel-Choi 2020). Almost two decades later, such deeply embedded sentiments fuel populist politics. In addition, given that the disintegration process of Yugoslavia awakened the 'dehumanization syndrome', the latter in turn could generate not only a feeling of autophobia but would also have been accompanied by a denial of identity and nationality (see Komel, 2019). Then, the end goal would be to limit communal tensions rooted in rival historical memories (for example, between Serbia and Croatia), to avoid the factionalisation of political loyalty and subsequent massive mobilisation (see Arf 1998). Following this line of reasoning, the biggest issue for the ruling party would be to maintain the internal sovereignty of the State which would be legitimised by its foreign policy and/or subsidised by international donors (state narratives supporting economic reforms have been, for a long time, oriented towards the International Monetary Fund/IMF). Nonetheless, adverse geopolitical tensions (Kosovo) and/or deteriorating economic conditions (any crisis like the one intertwined with the health crisis resulting from COVID-19 in 2020) can create legitimacy dilemmas for the political establishment, and ultimately lead to the collapse of state authority.

In the Serbian collective imagination, Kosovo is a central subject, with a high emotional charge (it should be noted that this calls for regular evaluation and does not affect all segments of the population with the same intensity) and may be perceived as a 'lost territory'. Such a loss has certainly caused cultural trauma and has generated policies based on feelings of insecurity (Korsten 2019). That is to suggest that the history and myths surrounding Kosovo, as well as recent events and the game played by external actors, have influenced the construction, reconstruction and evolution of identity narratives by the ruling elite not anymore along ethnic criteria/lines but around 'regional stability' and related 'feelings of insecurity'. As such, 'international (in) security' is not entirely materially given, it is above all socially constructed according to Ejdus (2016).

Thus, one may agree with Patalakh (2018), for whom the foreign policy of the ruling party is founded on realism and emotions, and thus treat the coun-

9 Moreover, from 2015 to 2020, I regularly asked this question to a wide variety of people. The dominant response I got from the older ones (those over 65 ) was 'There's nobody else...'. 
try's EU accession process in terms of 'pragmatic maximization of utility' and apprehending its relations with foreign powers such as Russia on an identity line. Such an attitude is particularly reflected in the regular use of historical analogies concerning Russia and more recently China, as well as the memory of the 'traumas' experienced in the 1990s and 2000s, knowing that Aleksandar Vučić has personal memories of these events (more precisely with regard to Kosovo and the NATO bombing campaign in 1999). It is useful to recall what he said in 2005. While a member of the SRS, he said that Serbian President Boris Tadić's proposal to resolve the issue of Kosovo and Metohija is different from his government's plan, which is now a proposal to grant conditional independence to the province (division into two entities), and that it is a 'dangerous proposal' (Kurir 2005). All this to argue that Serbia's foreign policy under the SNS has evolved at the discretion of the statements and concrete actions of its ruling elite, but that it is above all its equivocal character that challenges.

Ultimately, the true face of his foreign policy revolves around the 'free will vs. determinism' debate. In other words, to what extent does the behaviour of the party in power result from the action of external forces over which it has no control, or is it able to decide for itself to act or to behave in a certain way? On the one hand, it looks to be rooted in Yugoslavia's non-aligned posture also known as the 'Third way' between East and West. In 2020, one of Aleksandar Vučić's statements seemed to corroborate this position: 'Russian President Vladimir Putin understands Serbia's problems very well', and he (speaking of Aleksandar Vučić) told everyone that he is 'neither Russian, nor American, nor German, but only a Serb who works for Serbia' (Srbija Danas 2020). On the other hand, an alternative reading of the previous statement might echo one of the fundamental historical characteristics of Serbia's past, which is that, for many centuries, Serbs have not been the masters in their own house (Cox 2002). To summarise, I suggest considering the foreign policy of the ruling elite through the prism of heteronomy ${ }^{10}$ with reference to the pretstava, namely the image that the country is eager to portray to foreigners, which occupies a very important place in the local culture, whether at political or individual levels. The ruling elites must therefore find a balance between pragmatism (vis-à-vis the EU and the international community) and popular resentment, resulting in a difficult balance to achieve (Tournois 2021).

With emphasis on the evolving narratives of the ruling party, four periods emerge which symbolise qualitative changes with regard to minority rights (LGBT, migrants), Kosovo and the state of democracy in Serbia. They are discussed in the following sections.

10 The underlying assumption is that Serbia lost its autonomy after the break-up of Yugoslavia and, as such, has lost moral agency given the atrocities Serbs were accused of. Consequently, heteronomy is here understood as the ontological dependence to act morally on the relationship between oneself and other agents, that is to say that an agent does not act independently of external constraints (Meade 2017). 


\section{2-2014: The nationalist legacy}

The parliamentary and presidential elections, which were held in Serbia in May 2012, resulted in a change of government. Since the overthrow of Slobodan Milosević in 2000, Serbia has been ruled by coalitions gathered around the two main democratic parties and their leaders, from Zoran Đinđić to Vojislav Koštunica and finally Boris Tadić. Their respective parties share a common ideological framework as they were formed in the early 1990s in opposition to the regime of Slobodan Milošević and the remnants of the communist apparatus (Simić 2013).

Serbia, unlike other post-communist countries and in particular the former Yugoslav republics which already joined the EU, was under scrutiny by foreign observers and EU officials. Expectations were high as the country did not appear to be affected by the wave of democratic, institutional and foreign policy changes that had unfolded at that time across Eastern Europe. The new ruling elite also had to contend with the legacy of previous governments on unresolved issues such as minority rights, Kosovo, and EU and NATO membership.

In June 2012, Tomislav Nikolić, a former radical, won the elections under the SNS banner and, from the start, held an ambiguous position. Barely elected, the Serbian president made several nationalist outings such as 'the project of a Greater Serbia is his unrealized dream' and that today if he respects the internationally recognised borders of the Republic of Croatia, he believes that the Croats do not have to return to Vukovar 'because it was a Serbian town'11 (Martens 2012). On the sidelines of the verbal escalation that followed with the heads of foreign governments, Serbian nationalism then emerged as being written in stone in the country's history. This will lead Subotic (2012) to note bitterly that, twenty years after the start of the Yugoslav crisis, the countries of the region seem to be stuck in accounts of the past which are contradictory and irreconcilable.

Seen from today, it looks like a last nationalist standstill, but at that time several countries in the Balkan region share the same characteristic with regard to the rights of lesbian, gay, bisexual and transgender (LGBT) people. Indeed, as Swimelar (2020: 2) points out, nationalism has been one of the national constraints to the advancement of LGBT rights, particularly in countries like Bosnia and Herzegovina and Serbia where identities and multiple narratives European, multi-ethnic, ethno-nationalist and religious' collide.

However, after two years in the prime minister's chair, it was relatively clear that Serbia had entered a dead end. An almost complete break with the (ethno-nationalist) past was deemed necessary as an implicit requirement in order to

11 The latter point was the subject of controversy, with Tomislav Nikolić saying he did not say 'Vukovar was a Serbian town' (https://www.rtv.rs/sr_lat/politika/nikolic-nisam-rekao-da-je-vukovar-sprski-grad_321763.html). 
restore the country's credibility on the international stage. Aleksandar Vučić probably understood that the SNS had to adapt to new circumstances and, to do so, it had to reduce the influence of the old parties that were still active on the Serbian political scene. In contrast to Slobodan Milošević in the 90s, Aleksandar Vučić has implemented an 'ethnic under-bidding' strategy, namely that he has depicted himself as the only moderate force competent to resolve the political crisis, while demonising the more radical groups by qualifying them as 'extremists' (Vujačić 2007). Generally speaking, opposition parties and their leaders have been stamped as 'those stuck in the past' helping Aleksandar Vučić to gradually consolidate the ruling party's regime.

It is known that symbolic events often mark the path of political parties, and Serbia is no exception. On 28 September 2014, downtown Belgrade hosted its first Gay Pride since 2010, under high police protection and closely scrutinised by the EU, which made it a human rights test for the new pollical establishment. As prime minister, Aleksandar Vučić warned that 'anyone who tries to provoke incidents will be punished particularly severely'. Members of his cabinet announced their participation, including Minister for European Integration Jadranka Joksimović, and Tanja Miscević, chief negotiator for EU membership, as well as Minister of Culture Ivan Tasovac, thus offering public support for the Gay Pride's organisation staff and participants for the first time since 2010. From then on, and in parallel with what happened after the fall of Slobodan Milošević, financial support will only come to the extent that the IMF and the EU, as main donors, remain satisfied with the pace of internal reforms and cooperation with major international institutions.

\section{4-2017: Setting an (EU-driven) agenda}

The year 2014 was characterised by a lack of visible progress on several key issues related to the EU accession process, which again called Serbian citizens to the polls. After the victory, Aleksandar Vučić portrayed himself as a 'reformer' and pushed for increasing the opening of chapters as part of his EU-driven politics (in the sense of 'conditionality' and less in that of 'Europeanization'). He then declared: 'You cannot rule in Serbia and do anything without a bottom line... We have tough reforms ahead of us, after all we've done... If people want to listen to good stories, all right, let them vote for another' (Analitika 2014). His narratives hence emphasised a form of (mostly internal) 'Realpolitik' based on the possible, neglecting abstract agendas and value judgments, and whose sole objective is efficiency. The dark side of this political strategy is that it leaves out 'doctrinal, principled or moral considerations'. In fact, it echoed a drastic change that took place at the beginning of the 2000s, when the indirect choice based on loyalty to the party, to an ideology (socialism) or even to the nation switched to real facts and rational criteria (Mihailović 2001). The corollary of this trans- 
formation has led the ruling party, as part of its implicit new national project, to 'denationalize' Serbian citizens and/from their grounding, to influence the perception of survival (minimum standards) by focusing and communicating regularly on average salary increases in Serbia compared to other countries in and outside the Balkan region, and ultimately to 'buy' or even 'force' commitment to electoral participation.

This victory, associated with a weak legitimacy resulting from the ballot box, leads to underline certain characteristics of the political system in place, namely the low proportionality which testifies to an 'immutable institution', a 'closed' list of candidates and a relatively low electoral threshold (Jovanović 2014). Either way, EU officials have given the ruling party an a priori satisfecit, while setting its political/reform agenda for the years to come. Catherine Ashton, the EU's representative for foreign affairs, was the first official to congratulate Serbian citizens on the parliamentary elections. At the same time, the European High Representative for Foreign Affairs and Security Policy recalled one of the priority expectations of Brussels vis-à-vis the new government in Belgrade: 'Former First Deputy Prime Minister Aleksandar Vučić got an excellent result. It has been an important part of the dialogue between Belgrade and Pristina. We hope that these negotiations will continue, which he himself has made clear' (Maksimović 2014). As the same story repeated in 2016 (and again after each further voting, the climax being 2020) following another round of elections, journalist Aleksandar Apostolovski named it 'the Vučić phenomenon': while he received 60,000 new votes, at the same time he lost 27 seats in parliament 'because almost all opposition parties skipped the census, so he did not feel the benefits of scattered votes' (Apostolovski 2016).

One of his first major political initiatives materialised in the form of a 'charm offensive' during the promotion of the newly established Serbia-Germany Forum. This maneuver, which notably concerned the growth of economic exchanges between the two countries, left two impressions: a 'tireless reformer' and a 'regional conciliator'. To politicians, businessmen and journalists alike, he appeared more as an 'ambitious reformer of European caliber than a former nationalist'. As a result, he benefited from the complacency of German journalists as no one asked him about his past during the interviews. It was also a highly symbolic turning point in the sense that he repeatedly referred to the reforms initiated by Zoran Djindjić and which, according to him, stagnated for an entire decade (Rujević 2014). Since Ruzica Djindjić, the widow of the slain prime minister and a friend of Germany, was seated at the same table, this was an implicit way of showing repentance and asking for forgiveness. Such behaviour is an integral part of the 'halo effect' tactics Aleksandar Vučić has regularly implemented with a variety (but selectively) leaders such as Vladimir Putin, in an attempt to present himself as an independent politician to internal as well as foreign audiences. 
The support his government has received from EU officials and heads of state of EU countries should not mask the disappointing human rights state in Serbia. Green MEP Volker Beck expressed a negative opinion of the situation of minorities (and in particular the Roma) in Serbia. As part of the attributes of a modern nation, 'Gay Pride must become a normal thing' at least on the activists' side (Rabrenović 2015). Elsewhere, the 2015 report by the Helsinki Committee for Human Rights in Serbia highlighted the 'refusal of the Serbian elite to face the consequences of Milošević's policies' and the insufficient 'liberal democratic traditions' that exist in Serbia throughout state and civil society levels. Interestingly, the ruling party (SNS) is not included in the traditionally conservative bloc - comprising political parties (Democratic Party of Serbia, Dveri, Serbian People's Party), intellectual circles, the Serbian Orthodox Church, universities, tycoons and the media (Helsinki Committee for Human Rights in Serbia, 2016). This view has been one of the driving forces behind the demobilisation of internal opponents and the marginalisation of far-right groups.

Regarding its foreign policy, the decision of the Serbian authorities to embark on a process of normalisation with Kosovo has left observers wary. Rather than a 'Europeanization' process, with foreign experts arguing for placing the Serbia-Kosovo dialogue under the auspices of the EU, the policy shift that took place looked more like bilateral talks based on common interests (pragmatism) and political opportunism rather than 'absorption, adaptation, convergence or identity construction' within the EU-Serbia-Kosovo triangle, which Economides and Ker-Lindsay (2015) theoretically qualify as rational policy and instrumental 'pre-accession Europeanisation' rather than as a process of 'adaptive normative Europeanisation'. Aleksandar Vučić's (updated) position must be put in perspective with his previous statements regarding the territorial integrity of Kosovo. In 2012, he declared that there was a misunderstanding with the EU and that 'Serbia is/was ready to continue the dialogue with Pristina, and that the territorial integrity of Kosovo, mentioned in the enlargement strategy of the EU, means/meant that there is/was no partition of Kosovo' (Danas 2012). ${ }^{12}$ In 2015, he declared in the television news that 'it is only together that we can ensure the preservation of the state and national interests, as well as economic prosperity' (Dnevnik 2015). ${ }^{13}$

The break with the last ethno-nationalist vestiges had therefore not yet been finalised. It will come (in part) with the departure of Tomislav Nikolić, a symbolic manner for Aleksandar Vučić to 'kill the father' and, someway, to show his willingness to harmonise his potential with the demands of the time, in new international circumstances.

12 Istinomer (2018): 'Vučić o Kosovu, nekad i sad', Istinomer (28 August): available at: https://www.istinomer. rs/amnezija/Vučic-o-kosovu-nekad-i-sad/.

13 Istinomer (2018): 'Vučić o Kosovu, nekad i sad', Istinomer (28 August): available at: https://www.istinomer. rs/amnezija/Nučic-o-kosovu-nekad-i-sad/. 


\section{7-2020: Reforms and regional stability backed by a continuous decline in democracy}

The most important period in Serbia under the leadership of Aleksandar Vučić was probably 2017-2020. The policy changes that have arisen have been legitimised by stigmatising the Serbian opposition (progressives and modernists vs. 'those stuck in the past'). This made it possible, at a lower cost, to forget the past (or liabilities) of the actors in power and to build a new image closer to the expectations of the international community and more particularly of the EU.

Following the end of the five-year term of Tomislav Nikolić (31 June 2017), newly elected President Aleksandar Vučić put the 'modernization' of Serbia at the forefront of his political agenda. Designating the 'openly gay' Ana Brnabić as Serbia's first female prime minister on 15 June 2017, sent a strong signal to foreign observers, political analysts and EU officials. In her induction speech, she bluntly summed up the country stakes: 'The time before us will show how brave we are to move boundaries', she said. 'Now is the moment to make a step forward and take our society, country and economy into the $21^{\text {st }}$ century' (Gec 2017). This appointment caused a shock wave both within the coalition which governs Serbia, as well as in the conservative/nationalist opposition as among the deputies of the political formation of the Serbian president and within the Orthodox Church (Curovic 2017). The media were the bearers of the 'new order' to be established in Serbia. For instance, the ruling party condemned the explicit hate speech of the Dveri Movement towards the LGBT community. 'Those who falsely advocate for greater family rights by attacking citizens who may have different sexual orientations than them, are showing a naked policy of hatred and intolerance by Bosko Obradovic' the SNS said in a statement (Tanjug, 2017a). Nominating her as the new head of Serbia's government was logically, not to say rationally, imbued with pragmatism: 'I don't care, it's her right, I'm interested in her result. She is a woman who has done a lot for all of us', said the president answering a question about Minister Ana Brnabić's sexual orientation. The LGBT community described the move as a 'historic moment for Serbia' (G.K. 2016).

Her appointment was also aimed at lifting the remnants of ethno-nationalist tendencies linked to the old ethnic divisions between Serbs and Croats. Filip David, the Serbian writer of Jewish origin, warned against rising nationalist tensions between the two countries (see Vurušić 2017). Ana Brnabić is from Stara Baška on the island of Krk in Croatia. Her ('unexpected') nomination was reported by the popular Croatian daily JutarnjiLIST using irony, turns of phrase, figures of speech and implicit references to the conflict between Serbia and Croatia during the dissolution of Yugoslavia: 'She bathed with friends and childhood friends on the Počešna beach not far from the house where she found peace. Until, as in the Partybreakers' "1000 years" song, the cell phone rang 
and "a call that changes everything" reached Stara Baška. And the invitation came from the prime minister, but not the Croatian, but the Serbian, Aleksandar Vučić' (Jurković 2017). Curiously, Aleksandar Vučić's decision came only a day after Leo Varadkar, 38, was officially elected prime minister of Ireland, becoming the first openly gay man to hold the post (AFP 2017).

Although it would have been more appropriate to see this decision as a way to move Serbia away from 'intolerance' and 'hatred speeches' rather than a radical change in the course of its history, there has been much criticism, which is, in a way, inevitable. As Berliner Tageszeitung argued, Serbian President Aleksandar Vučić supports Gay Pride but only because the EU insists on respect for human rights in the accession negotiations (Roscic 2017). For their part, some LGBT activists consider his appointment as a purely facade commitment and accuse the Serbian president of wanting to 'buy' exemplary behaviour on the issue of homosexual rights, among other things to distance himself from the politics of Russian President Vladimir Putin (Chenouard - Millotte 2017). Compared to Bosnia, it was as a result of strong external pressure that the rights and visibility of LGBT people rose, which in turn led to stronger activism and change; the holding of the first Gay Pride festival appeared to reveal that ethno-nationalist challenges may diminish as (legal) norms relating to LGBT rights are strengthened (Swimelar 2020). Regardless of where the criticism came from, it was a tactical move towards EU standards and the scope of which extended beyond LGBT rights.

The debate on the migrant crisis has provided the ruling party with yet another opportunity to assert its position and move further away from the past. Over the past two decades, the countries of the Danube region have experienced a very significant decline in their population, which could hamper rapprochement with EU member states. World Bank projections suggest that if the Western Balkans maintain an average growth rate of around $3 \%$, it may take six decades for the region to economically converge with EU member states (Bonomi - Reljić 2017). Moreover, given the prevailing feeling among the population of the Western Balkans that nothing will change, Serbian citizens, as well as their alter egos from other former Yugoslav republics are increasingly willing to emigrate to Western countries in search of a better life and better employment opportunities (Vračić 2018). This is particularly the case of qualified young Serbs as evidenced by the global ranking of countries with the highest 'brain drain'14. Radonjić and Bobić (2021) argue that the (massive) emigration of highly skilled individuals considerably weakens local democracy and social cohesion in Serbia. The main conclusion to be drawn from this situation is that

14 According to the Global Competitiveness Report released by the World Economic Forum in February 2020, Bosnia and Herzegovina (BiH), Croatia, North Macedonia and Serbia are among the top-ranked countries with the biggest brain-drain in the world (European Western Balkans 2020). 
migratory flows and the prolongation of the working life of the active workforce can compensate for this demographic fall (Savić - Dakić 2016).

These observations combined with external pressures led to the unexpected stance taken by Aleksandar Vučić on the migrants' crisis. Responding to citizens' questions on Instagram, the president of Serbia recalled the country's low fertility rate and said salvation is undoubtedly in bringing people to the region, regardless of their nationality, 'so that we may we survive as a nation and as a country' (Beta 2019). On the one hand, these narratives are part of the president's multi-target comparative strategy on 'ethnic underbidding', whether aimed at foreign observers or opposition politicians in Serbia, and in particular the far right which seeks to 'frighten Serbs with migrants'. To criticism from sovereignists and far-right groups concerning Germany and its Chancellor Angela Merkel, whom they consider to be the instigator of such a policy, Aleksandar Vučić replied: 'I do not have the kind of fear of migrants that anyone else in our country has for reasons unknown to me. Some have done the right thing, which is why Angela Merkel is one of the greatest leaders in modern Europe', as reported by srbin.info (2018), a far-right internet portal. This statement could paint a new model for Serbia as a country providing low-skilled labor for large foreign companies that 'will enslave us economically. Instead of solving the core problem with measures to boost birth rates, as well as boosting domestic economic growth, Vučić turns to his mentor from Germany, which needs a cheap workforce in the Balkans to wind cables in their factories, and undoubtedly continues its policy of banking globalization and the whole of the Balkans' according to Dosta je bilo $(2019,2020)$. The latter, whose name means 'Enough!', is a sovereignist party and has used the debate on the migrant crisis as a springboard for its political leader Saša Radulović, former minister of the economy, to stand in the next elections to Belgrade (Radulović - Prelec 2016). His plans were virtually 'nipped in the bud'. Above all, the issue of migrants has not mobilised much of the opposition, thus revealing a far from unified front. In the end, the ruling party most certainly blurred the lines and opened the door to more conservative positions from the right to the far right whose rhetoric revolved around 'colonization', 'disappearance of Serbia', 'sovereignty' and opposition to globalisation.

On the other hand, his statements may implicitly resonate as a form of resignation from the economic backlog, despite the government's self-righteous speeches about the country's economic development. They thus reflect the structural weaknesses of the internal policy implemented since 2012 with the aim of establishing economic, legal and social conditions similar to those of EU member states.

Aleksandar Vučić's entry into the debate on the migrant crisis (while he may have definitely turned the ethno-nationalist page, at least rhetorically) as well as the appointment of Ana Brnabic have tacitly brought to the fore the old 
rhetoric of arguing that Serbia is not master of its own destiny. This is one of Serbia's most powerful cultural peculiarities when it comes to politics. First of all, if they have helped to marginalise the nationalist right (Dveri) and far-right (Naši), these decisions have also stigmatised (not necessarily negatively from the point of view of the population) their recurring narratives which consist of designating 'who backs who'. For example, while his coalition partners reacted in unison, the conservative opposition party accused the new head of state of succumbing to pressure and influence from Washington, and that Brnabic was not at all his choice, but a decision imposed on him by the West (Al Jazeera 2017). The leader of the Dveri, Boško Obradović, said her selection was 'the result and continuation of the policy of the colonial position of our country, continuation of subsidizing foreign companies, sale of economic and natural resources, "leasing of our workers"' (Tanjug 2017b).

Then, under the leadership of Ana Brnabić, what was implicit in 2014/2015 became the recurring theme underlying the relations between Serbia and Kosovo; that is to say, 'whether the presidents of the two countries - Aleksandar Vučić and Hashim Thaci - were conducting secret negotiations on the division of Kosovo' (Karabeg 2018). Such two-sided talks would de facto exclude Federica Mogherini, the EU's High Representative for Foreign Affairs. As reported in various media, the partition of Kosovo did not receive the support of the EU and Germany (Trivić 2018) because this option could cause instability in other countries in the Balkan region, while this option seemed to please Russia (Radio Slobodna Evropa 2018). In short, Ivica Dačić, the head of Serbian diplomacy, probably best summarised the situation: 'We are brought to the point that today the story of the EU cannot be no bait for anyone because it is not about the near future. What can they offer us if we agree with Priština [the capital city of Kosovo]? Entry into the EU? Well, it [EU] can't, there is no EU enlargement. If the EU wanted, all this would take much shorter'15 (Tanjug 2019).

The point here is that it gives substance to the Serbian government's new foreign policy doctrine on the entire Balkan region which is 'regional stability'. 'Vučić, with the full support of the Serbian government, is trying to find a solution to the decades-long problem in order to ensure long-term peace and stability in Kosovo and Metohija, mainly for Serbian citizens', said Ana Brnabić (Beta 2018) ${ }^{16}$. The backlash from the shift from 'reforms' to 'stability' led local experts, politicians and foreign analysts to qualify the political system set up by Aleksandar Vučić as a 'stabilocracy', that is to say 'stability before democracy': 'Vučić enjoys the support of Brussels and Chancellor Angela Merkel, despite the

15 During that interview, he also replied to those who argue that he is a 'Russian man': 'They are fools. I am neither a Russian nor an American man. I only work for Serbia. But I am in a position that whenever we have a problem, I can rely on my brother Sergei Lavrov' (Tanjug 2019).

16 This declaration alone deserves a full-fledged analysis because it refers specifically to 'Kosovo and Metochia' which implies a Serbian province and not an independent state. 
fact that media freedom and the rule of law in Serbia have been receiving poor marks in European Commission reports for years, not to mention democratic culture and political communication... Vučic is allowed to develop an autocratic regime as long as he does his regional homework...' (Roščić 2017). Kapidžić (2020) added that the democratic decline in Serbia as well as in other countries of the Western Balkans and in the former Yugoslav republics is based on common causes stemming from the weak institutions and practices of governance inherited from the past which preserve executive dominance, favouritism and informality. In a way, this observation foreshadowed the shift that occurred in 2020 during/or thanks to the management of the COVID-19 pandemic.

\section{Onward: towards growing authoritarianism}

The year 2020, under the pandemic gaze, was as important as 2017, reflecting a kind of 'headlong rush', and during which it became relatively clear that 'Vučić is using the coronavirus to strengthen his influence' (Beta 2020). The impression left by this very particular year, as a conclusion of the period that began in 2012, is that the political establishment was finally looking for a political identification and motives which in turn generated momentum and established requirements.

Daily television performances began with the 6:00 p. m. briefing where local medical experts (grouped together as a 'crisis team' or krizni štab) gave regular updates, apologising for not being used to talk to media while acknowledging that they (journalists) are deemed necessary, to finally announce the arrival of specialists from China who have come to share their experience and knowledge on how to fight COVID-19. The rhetoric of viewing journalists as 'the enemies of the state' seems to not only be the prerogative of President Donald Trump's political communication but a worldwide communication pattern for populist leaders across the globe (Kulić 2020). Moreover, the president presenting himself as 'the savior of the nation', updated some sort of hegemonic project. Furthermore, stamping the Serbs who returned from abroad as 'immigrants', held the characteristics of an illiberal method that violates the autonomy and dignity of the person (Glasius 2018). These discursive practices may reverse the course of history and revive the backward principle of the governing role of the (Communist) Party, when party organs and those of the state were inseparable.

The pandemic somewhat appears as the epitome of an episode that started in 2012 when the SNS came to power. Many observers prefer to remember the very first words of Aleksandar Vučić as Serbia's prime minister during a party meeting held on 21 October 2013: 'We do not hide that our objective is and I will say it openly in front of you this Evening for the first time, our goal is for Serbia to become a full member of the European Union by 2020, and we will accomplish this task. And you know, unlike the others, when we say we're going to do our 
job, then that's for sure'. ${ }^{17}$ Two years later, his declaration in Bratislava about EU membership ('Serbia is a full member of the EU until 2020!') was commented upon very positively: 'We deserve to enter the EU. We have done a lot, and we will do a lot more. We trust Prime Minister Vučić, because he does what he promises and proves what he has proven many times!' (Fonet 2015). Following the June 2020 parliamentary elections, it was expected that the European Commission reports on Serbia and Montenegro would not be positive. They weren't. Moreover, the health crisis was the backdrop for a verbal escalation, particularly between the government and the EU, in reality reflecting the true state of the country in terms of the rule of law, (weak) media freedom and human rights violations (see Stojanović 2020). One of the Serbian president's declarations probably went unnoticed in 2017 although it summarises state's ideological recomposition with an implicit reference to the Kosovo issue: 'Socialism with Chinese characteristics means something very important - that China preserves its independence, its foreign policy and sovereign state', he said (Beta 2017) ${ }^{18}$.

Thus, the Serbian political elite, through a set of top-down narratives, has (re)constructed, at least implicitly, the imagined East ideologically, politically, economically and socially, thus bringing back to the political and public arenas old categorisations and associated stereotypes. The popular German daily newspaper DW recently put the appointment of Ana Brnabic back on the front of the stage. The title of the article 'Ana Brnabić: A female leader who is unlikely to change history', contrasted with some of the positive headlines in the foreign press, published after she was nominated as prime minister of Serbia in 2017. The narrative style used left no doubt about how wide the gap is between expectations ('nothing like a typical Balkan politician', 'change', 'the Conservative Balkan nation') and reality ('just another team player in Aleksandar Vučic's well-trained squad with no actual power', 'same mindset as her close ally, Aleksandar Vučić') (Kljajic 2021).

Does it signal a return to nationalist behaviours? 'Virulent nationalism', that which 'rejects the status quo and seeks to reaffirm the will of a community imagined in a political or cultural space' (Bieber 2018b: 2) is (still) the prerogative of several groups of right-wing extremists since the start of the new millennium (see Jovanović 2018). Given the qualitative and quantitative makeup of the opposition in the Serbian parliament, the current political regime could hardly be called 'competitive authoritarianism', the very one that dominated the Western Balkan countries throughout the 1990s (see Bieber 2018a). Under the pretext of fighting the pandemic, the political elite has actually aligned the Serbian national project with authoritarian Chinese nationalism (Tournois 2021). The fight

17 See https://www.istinomer.rs/izjava/nisam-rekao-da-cemo-sigurno-u-eu-do-2020/.

$18 \mathrm{He}$ also pointed out that China always makes decisions independently and in accordance with international law, which may tacitly refer to the bombing of Serbia as a sovereign state in 1999 and the self-determined independence of Kosovo in 2008. 
against the pandemic has also shaped a new form of 'exclusionary nationalism' (Bieber 2020) which has materialised in prejudice against certain groups of Serbian citizens. It recalls a historical lesson that could be drawn from the case of Yugoslavia, namely that the national question in itself is a phenomenon which arises in particular circumstances and that 'nationalist sentiment' is generally motivated by political considerations (see Vladisavljević 2007).

\section{A necessary perspective}

As a preamble to the conclusion and before delineating future research directions, I aim to briefly put the findings into a comparative perspective articulated around opposition parties in Serbia.

One of the pillars of the regime's 'ideological recomposition' lies in the strategy of 'demonizing' the opposition and its supporters, treating it practically as a 'systemic error', a 'necessary evil' that must be tolerated in the name of European integration (Štavljanin 2019). The end of 2019 witnessed an 'old-new' component added to this strategy that is victimisation. While the opposition 'draws a difference between themselves and a decent Serbia that wants to talk about roads, salaries, pensions, work', Aleksandar Vučić stressed that its leaders use a similar methodology as in the past in the magazine Identitet ${ }^{19}$, which had the front page 'Djindjić on the target of a lone sniper' (Politika 2019). The low turnout in the 2020 legislative elections would nevertheless suggest that the recurring negative campaign against opponents could have negatively influenced individuals' perceptions of political effectiveness, confidence in the regime and the community's general attitude (Lau - Sigelman - Rovner 2007). On the other hand, some analysts are more critical of the Serbian opposition itself because 1) it ultimately differs little from the ruling elite in terms of the content of their program, albeit general ${ }^{20}$, and 2) its achievements are recorded in the biography of its leaders who regularly 'rebrand' themselves as the saying goes: 'old faces in a new wrapper' (stara lica u novom pakovanju). While opposition party politics were partly responsible for the overthrow of Slobodan Milošević's regime in October 2000 (see Bieber 2003), in its current 'form' it failed to seriously threaten the governments that followed one another after 2012, but it also paved the way for the election and re-election of Aleksandar Vučić. As it presents itself today in Serbia (and, by extension, in the Balkans in general), political competition deserves a closer examination and in particular its influence (or not) on the attitudes of public opinion vis-à-vis the political establishment but also concerning more specific themes such as national identity, the state of democracy, etc.

19 'Identitet' means 'Identity'. It is the journal of the Montenegrin diaspora.

20 Interestingly, while Serbian opposition use the term 'so-called Kosovo', state narratives mention 'Kosovo and Metohija' (Beta 2018), both players de facto do not recognise the independence of the (former) Serbian province. 
The corollary of this strategy is control of the media combined with a gradual and increasing censorship of (almost) any negative commentary on the decisions of Aleksandar Vučić. For example, between 1 December 2020 and 31 January 2021, 'the Serbian president was positively represented up to 82.6 percent of the time on TV channels that use the national broadcast frequency, and at the same time he has never been presented in a negative context', according to the Bureau of Social Research (BIRODI) (Nova.rs 2021). Even Slobodan Milošević, who had won the elections for the Serbian Federal Presidency and then for the Federal Presidency of Yugoslavia, while harassing opposition movements, had never established a 'full-fledged dictatorship' (McFaul 2005). In Republika Srpska (a Serbian enclave in Bosnia and Herzegovina), thanks to the international community, journalists stressed that there was no lynching and targeting of political dissidents, as is the case in Serbia (Direktno 2020). In short, the complete occupation of media and political spaces by the ruling elite, supported by a structurally weak and divided opposition, has not only prevented democratic development but has also regressed Vučić's/Serbia's regime type to competitive authoritarianism (Castaldo 2020). As a result, the government ultimately alienated both EU and Serbian citizens given the low turnout in parliamentary elections, the lack of credible alternatives to the ruling party and suspicions of fraud.

\section{Conclusion}

Forced democratisation without the necessary institutional structures might best sum up Serbia's trajectory over the past two decades. It has to be traced back to the very early post-Milošević days when expectations were very high about the creation of the preconditions for the transformation from authoritarian order to democratic order. Indeed, Sekelj (2001: 95) highlighted that the government that followed gradually abandoned the very process of structural transformation of the system and 'instead it followed the rules of the game of the system that it inherited, it placed its own people in important offices and put the state, media and institutions under its control'. This argument reverberates the blunt comments about Serbia made by former German diplomat Gudrun Steinacker. ${ }^{21}$ To a certain extent, Aleksandar Vučić's political style both borrows from and opposes the German conservatism of Greiffenhagen (1979) with the starting postulate that particular institutional structures (authoritarian institutions as opposed to democratic institutions) predetermine the political and social life. From 2017 to 2020, there would be the idea of an 'organic' conception of state and society with some form of loyalty. The year 2020 has come to contradict these principles and illustrate a firm 'absolutist' drift and the replacement of

21 See https://www.dw.com/sr/balkanom-vladaju-kleptokrate-uz-blagoslov-eu/a-54315153. 
the old institutions (at this stage, the map of political parties elected to the Serbian parliament in June 2020) by 'a rational structure designed for the benefit and effective functioning of a new artificial political machine' (Greiffenhagen 1979: 611) which ultimately contradicts the national project to rebuild Serbian society along modern lines. Actually, in a constant dialectic between being and acting, the post-communist state that has been shaped during this period combines autocratic, (domestically) fractious and personalistic ideals as defined by Grzymala-Busse and Luong (2002).

The preceding discussion questions the perspective to be adopted in order to provide a more in-depth analysis of the political situation in Serbia and thus opens the door to additional investigations. The starting point is to consider that placing excessive hopes in the leaders and political parties of a country and neglecting the crucial role of a 'truly autonomous' civil society can be a source of great frustrations, as de Souza (2020) has pointed out, taking the example of post-Mandela South Africa. Citizens' protests that have taken place across Serbia under the slogan 'One in five million' support this argument. They showed that many Serbs were unhappy with the situation, but/and what started out as a 'walk with a purpose' made up of ordinary people died out as the opposition gradually joined the march until it finally took the lead ${ }^{22}$. The massive demonstrations which then took place in several cities in June 2020 during the legislative elections, exhibited that heterogeneous groups of individuals interacted, sometimes brutally, with various and occasionally opposing demands, calling into question the (non-)existence of a collective identity and illustrate the 'ambiguities inherent in the relationship between the singularity of a personal identity and the multiplicity of social identities that can be carried by a person' (Calhoun 1991: 59). This suggests that the 'new national project' initiated by Aleksandar Vučić since his first term in office has confused and fragmented Serbian society (or drustvo). Therefore, investigating how identity convergence and divergence intertwine and affect the trajectory of protest movements (e.g. Stoecker 1995) in contemporary Serbia, may provide additional insights into the shaping of collective action compared to the 1990s-2000s period.

22 I have been watching them every weekend during the Winter period. Whenever it was snowing or cold, these protests released a positive energy that was not politically articulated. It vanished when it started to be instrumentalized and turned into a sort of electoral fair. 


\section{References}

AFP (2017): 'Openly Gay Ana Brnabić Set to Become Prime Minister of Serbia', DW (15 June): available at: https://www.dw.com/en/openly-gay-ana-brnabic-set-to-become-prime-minister-of-serbia/a-39270285 (20 March 2021).

Alexander, James (2013): The Contradictions of Conservatism. Government and Opposition 48(4): 594-615.

Al Jazeera (2017): ‘Opozicija: Vučić je Izabrao Anu Brnabić po Nalogu Zapada', Al Jazeera (16 June): available at: https://balkans.aljazeera.net/news/balkan/2017/6/16/opozicija-Vučic-je-izabrao-anu-brnabic-po-nalogu-zapada (17 March 2021).

Allen, David Y. (1981): Modern Conservatism: The Problem of Definition. The Review of Politics 43(4): 582-603.

Alvarez, Mike - Cheibub, José Antonio - Limongi, Fernando - Przeworski, Adam (1996): Classifying Political Regimes. Studies in Comparative International Development 31(2): 3-36.

Anckar, Carsten - Fredriksson, Cecilia (2019): Classifying Political Regimes 1800-2016: A Typology and a New Dataset. European Political Science 18(1): 84-96.

Apostolovski, Aleksandar (2016): 'Fenomen Vučić', Politika (25 April): available at: https://www. politika.rs/sr/clanak/353811/Феномен-Вучић (12 March 2021).

Arfi, Badredine (1998): State Collapse in a New Theoretical Framework: The Case of Yugoslavia. International Journal of Sociology 28(3): 15-42.

Barlovac, Bojana (2010): 'Vojislav Kostunica - The Nationalist', Balkanlnsight (5 October): available at: https://balkaninsight.com/2010/10/05/vojislav-kostunica-the-nationalist/ (10 March 2021).

Beta (2017): 'Sinhua: Vučić Hvali Socijalizam s Kineskim Karakteristikama', N1 (13 October): available at: https://rs.n1info.com/vesti/a334721-sinhua-Vučic-hvali-socijalizam-s-kineskim-karakteristikama/ (25 March 2021).

Beta (2018): 'Boško Obradović i Ana Brnabić o Kosovu i Medijima u Srbiji', Beta (25 October): available at: https://beta.rs/politika/99757-bosko-obradovic-i-ana-brnabic-o-kosovu-i-medijima-u-srbiji (20 March 2021).

Beta (2020): 'Figaro: Vučić Koristi Korona Virus da bi Ojačao Svoj Uticaj', Danas (12 May): available at: https://www.danas.rs/politika/figaro-Vučic-koristi-korona-virus-da-bi-ojacao-svoj-uticaj/ (28 March 2021).

Bieber, Florian (2018a): Patterns of Competitive Authoritarianism in the Western Balkans. East European Politics 34(3): 337-354.

Bieber, Florian (2018b): Is Nationalism on the Rise? Assessing Global Trends. Ethnopolitics 17(5): 519-540.

Bieber, Florian (2020): Global Nationalism in Times of the COVID-19 Pandemic. Nationalities Papers: 1-13.

Bonomi, Matteo - Reljić, Dušan (2017): The EU and the Western Balkans: So Near and Yet So Far Why the Region Needs Fast-Track Socio-Economic Convergence with the EU, Stiftung 
Wissenschaft und Politik (December): available at: https://www.swp-berlin.org/fileadmin/ contents/products/comments/2017C53_rlc_Bonomi.pdf (10 March 2021).

Budding, Audrey Helfant (2002): The Man Who Overthrew Milošević: Vojislav Kostunica, One Year Later. The Fletcher Forum of World Affairs 26(1): 159-165.

Calhoun, Craig (1991): The Problem of Identity in Collective Action, in Huber, Joan, ed., Macro-Micro Linkages in Sociology, 51-75, Sage Publications.

Castaldo, Antonino (2020): Back to Competitive Authoritarianism? Democratic Backsliding in Vučić's Serbia. Europe-Asia Studies 72(10): 1617-1638.

Chilton, Paul A. (2004): Analysing political discourse: Theory and practice. Psychology Press.

Cox, John K. (2002): The history of Serbia. Greenwood Publishing Group.

Curovic, Kika (2017): 'Une Premier Ministre Homosexuelle dans une Serbie Conservatrice', Courrier International (16 June) : available at : https://www.courrierinternational.com/article/ europe-une-premier-ministre-homosexuelle-dans-une-serbie-conservatrice (7 March 2021).

Dérens, Jean-Arnault - Samary, Catherine (2000): Koštunica Vojislav, in Dérens, Jean-Arnault Samary, Catherine, eds., Les 100 Portes des Conflits Yougoslaves, 177-178, Éditions de l'Atelier.

de Souza, Marcelo Lopes (2020): The Land of the Past? Neo-populism, Neo-fascism, and the Failure of the Left in Brazil. Political Geography: available at: https://www.ncbi.nlm.nih.gov/ pmc/articles/PMC7139254/pdf/main.pdf.

Ejdus, Filip (2016): Diskurzivna i Praktična Konstrukcija Međunarodne (Ne)bezbednosti, in Jović, Dejan, ed., Konstruktivističke Teorije Međunarodnih Odnosa, 199-227, Fakultet političkih znanosti Sveučilišta.

European Western Balkans (2020): WEF: Four Balkan Countries Top Global Ranking With Giggest Brain Drain, EWB (3 February): available at: https://europeanwesternbalkans.com/2020/02/03/ wef-four-balkan-countries-top-global-ranking-with-biggest-brain-drain/ (20 March 2021).

Fonet (2015): 'Vučić: Srbija punopravni član EU do 2020. godine!', Telegraf (2 April): available at: https://www.telegraf.rs/vesti/politika/1505409-Vučić-srbija-punopravni-clan-eu-do-2020godine/komentari/svi (16 March 2021).

Fukuyama, Francis (2018): The Populist Surge. The American Interest 13(4): 16-18.

Gagnon, Jr., Valère Philip (2004): The myth of ethnic war: Serbia and Croatia in the 1990s. Cornell University Press.

Gec, Jovana (2017): 'Serbia's Next Premier: EU Membership, Modernization Priority', AP News (28 June): available at: https://apnews.com/article/5b86ff1223cf4ed6b0178e4172a7abf9 (10 March 2021).

Gellner, Ernest - Ionescu, Ghita, eds. (1969): Populism: Its Meanings and National Characteristics. Weidenfeld and Nicolson.

Giddens, Anthony (1991): Modernity and Self-identity, Stanford University Press.

G.K. (2016): 'Ana Brnabić, Prva Gej Ministrica u Vladi Srbije', Crol/LGBT news portal (8 August): available at: https://www.crol.hr/index.php/politika-aktivizam/8037-ana-brnabic-prva-gej-ministrica-u-vladi-srbije? $\mathrm{rCH}=2$. 
Glasius, Marlies (2018): What Authoritarianism Is... and Is Not: A Practice Perspective. International Affairs 94(3): 515-533.

Gordy, Eric D. (2010): Culture of Power in Serbia: Nationalism and the Destruction of Alternatives, Penn State Press.

Gorman, Gary E. - Clayton, Peter R. (1997): Qualitative Research for the Information Professional: A Practical Handbook, Library Association.

Greiffenhagen, Mortin (1979): The Dilemma of Conservatism in Germany. Journal of Contemporary History 14(4): 611-625.

Grzymala-Busse, Anna - Luong, Pauline J. (2002): Reconceptualizing the State: Lessons From Post-communism. Politics \& Society 30(4): 529-554.

Gustafsson, Karl - Krickel-Choi, Nina C. (2020): Returning to the Roots of Ontological Security: Insights From the Existentialist Anxiety Literature. European Journal of International Relations 26(3): 875-895.

Haidt, Jonathan (2016): When and Why Nationalism Beats Globalism. Policy: A Journal of Public Policy and Ideas 32(3): 46-53.

Helsinki Committee for Human Rights in Serbia (2016): Ljudska Prava u Srbiji 2015. Demokratski deficit - Osnova Autoritarnosti, Helsinki Committee for Human Rights in Serbia: available at: https://www.helsinki.org.rs/serbian/doc/izvestaj2015.pdf (17 March 2021).

Jenne, Erin K. - Bieber, Florian (2014): Situational Nationalism: Nation-building in the Balkans, Subversive Institutions and the Montenegrin Paradox. Ethnopolitics 13(5): 431-460.

Jovanović, Srđan Mladenov (2018): The Dveri Movement Through a Discursive Lens. Serbia's Contemporary Right-Wing Nationalism. Südosteuropa 66(4): 481-502.

Jovanović, Srđan Mladenov (2019): Confronting Recent History: Media in Serbia During Aleksandar Vučić's Ministry of Information in the Milošević Era (1998-1999). Hiperboreea 6(1): 61-74.

Kapidžić, Damir (2020): The Rise of Illiberal Politics in Southeast Europe. Southeast European and Black Sea Studies 20(1): 1-17.

Karabeg, Omer (2018): ‘Da li Mogerini razgovara sa Vučićem i Tačijem o podeli Kosova?', Radio Slobodna Evropa (12 August): available at: https://www.slobodnaevropa.org/a/most-podela-kosova-Vučic-taci-mogerini/29427749.html (10 March 2021).

Karolewski, Ireneusz P. (2020): Towards a Political Theory of Democratic Backsliding? Generalising the East Central European Experience, in Lorenz, Astrid - Anders, Lisa H., eds., Illiberal Trends and Anti-EU Politics in East Central Europe, 301-321, Palgrave Macmillan.

Kljajic, Sanja (2021): 'Ana Brnabić: A female leader who is unlikely to change history', DW (12 March): available at: https://www.dw.com/en/ana-brnabic-a-female-leader-who-is-unlikely-to-change-history/a-56850681 (30 March 2021).

Komel, Dean (2019): Post-Yugoslav Syndrome of Dehumanization, in Milisavljević, Vladimir Mićunović, Natalja, eds., Xenophobia, Identity and New Forms of Nationalism, 190-225, Institute of Social Sciences Belgrade. 
Korsten, Thijs (2019): Discursive Practices of Territorial Loss, Thijs Korsten Final Paper Student-Led Honours Seminar 'The Modern Balkans: History, Society, and Politics' (May 10).

Kulić, Milica (2020): Populist Communication in the Post-truth Age: A Comparative Analysis of Treatment of Journalists by Donald Trump and Aleksandar Vučić. Journal of Regional Security 15(1): 75-108.

Kürti, László (2020): Orbánism: The Culture of Illiberalism in Hungary. Ethnologia Europaea, 50(2): 62-79.

La Ferrara, Eliana - Bates, Robert H. (2001): Political Competition in Weak States. Economics \& Politics 13(2): 159-184.

Lau, Richard R. - Sigelman, Lee - Rovner, Ivy B. (2007): The Effects of Negative Political Campaigns: A Meta-Analytic Reassessment. The Journal of Politics 69(4): 1176-1209.

Levitsky, Steven - Way, Lucan A. (2010): Competitive Authoritarianism. Hybrid Regimes After the Cold War, Cambridge University Press

Maksimović, Marina (2014): 'Vučiću čestitke i poziv na reforme', DW (17 March): available at https://www.dw.com/sr/vu\%C4\%8Di\%C4\%87u-\%C4\%8Destitke-i-poziv-na-reforme/a-17502284 (10 March 2021).

Malka, Ariel - Soto, Christopher J. - Inzlicht, Michael - Lelkes, Yphtach (2014): Do Needs for Security and Certainty Predict Cultural and Economic Conservatism? A Cross-national Analysis. Journal of Personality and Social Psychology 106(6): 1031-1051.

Martens, Von Michael (2012): 'Die Serben durften nicht entscheiden, wo sie leben wollen', Frankfurter Allgemeine Zeitung (19 May): available at: https:/www.faz.net/aktuell/politik/ ausland/wahl-in-serbien-die-serben-durften-nicht-entscheiden-wo-sie-leben-wollen-11750937. html (11 March 2021).

Meade, Elizabeth (2017): Freedom Justified: Morality as Heteronomy in the Thought of Levinas. Dialegesthai. Rivista telematica di filosofia 18: available at: https://mondodomani.org/ dialegesthai/articoli/elizabeth-meade-01 (20 March 2021).

Mihailović, Srečko (2001): Politicke Formule Odrzanja i Promene Rezima u Srbiji. Republika 258: available at: http://www.yurope.com/zines/republika/arhiva/2001/258/258_16.html (15 March 2021).

Milisavljević, Vladimir (2019): Farewell to Universalism: Nationalism and Xenophobia After the 'End of History', in Milisavljević, Vladimir - Mićunović, Natalja, eds., Xenophobia, Identity and New Forms of Nationalism, 292-316, Institute of Social Sciences Belgrade.

Miller, William L. (1991): Media and Voters: The Audience, Content, and Influence of Press and Television at the 1987 General Election, Clarendon Press.

Mitzen, Jennifer (2006): Ontological Security in World Politics: State Identity and the Security Dilemma. European Journal of International Relations 12(3): 341-370.

Moffitt, Benjamin - Tormey, Simon (2014): Rethinking Populism: Politics, Mediatization and Political Style. Political Studies 62(2): 381-397.

Mudde, Cas - Kaltwasser, Cristóbal R. (2013): Exclusionary vs. Inclusionary Populism: Comparing Contemporary Europe and Latin America. Government and Opposition 48(2): 147-174. 
Nova.rs (2021): 'BIRODI: Vučiću nula minuta kritike na televizijama sa nacionalnom frekvencijom', N1 (28 February): available at: https://rs.n1info.com/vesti/birodi-Vučicu-nula-minuta-kritike-na-televizijama-za-dva-meseca/ (25 March 2021).

Orlović, Slaviša (2011): Partijska Scena i Predizborna Kampanja u Srbiji. Politički život (1): 7-12.

Patalakh, Artem (2018): Emotions and Identity as Foreign Policy Determinants: Serbian Approach to Relations with Russia. Chinese Political Science Review 3(4): 495-528.

Pavlović, Dušan (2020): The Political Economy Behind the Gradual Demise of Democratic Institutions in Serbia. Southeast European and Black Sea Studies 20(1): 19-39.

Politika (2019): 'Vučić: Opozicija sama crta razliku između sebe i pristojne Srbije', Politika (29 November): available at: https://www.politika.rs/sr/clanak/442992/Вучић-Опозиција-сама-црта-разлику-између-себе-и-пристојне-Србије (20 March 2021).

Procházka, David - Cabada, Ladislav (2020): Exploring the "grey zone": The Theory and Reality of "Hybrid Regimes" in Post-Communistic Countries. Journal of Comparative Politics 13(1), 4-22.

Racz, Krisztina (2009): Trauma ili Zabava? Secanje na Bombardovanje u Diskursu Simpoziona, in Djerić, Gordana, ed., Pamcenje i Nostalgia, 223-248, IFDT and Filip Visnjic.

Radio Slobodna Evropa (2018): 'Sekulović: Rusiji odgovara podela Kosova', Radio Slobodna Evropa (8 August) : available at : https://www.slobodnaevropa.org/a/sekulovi\%C4\%87-rusiji-odgovora-podela-kosova/29417478.html (29 March 2021).

Radulović, Saša - Prelec, Tena (2016): Saša Radulović: My Plan is to Become Mayor of Belgrade and Use that Platform to Win Serbia's Next Parliamentary Election, LSE European Politics and Policy (EUROPP) Blog: available at: http://eprints.lse.ac.uk/70181/ (25 March 2021).

Roemer, John E. (2001): Political Competition: Theory and Applications, Harvard University Press,

Roščić, Dijana (2017): 'Nevidljivi u Srbiji', DW (15 September): available at: https://www.dw.com/ sr/nevidljivi-u-srbiji/a-40525124 (24 March 2021).

Sekerák, Marián (2019): Towards Conservatism? Party Politics in Slovakia at the End of the 2010s. European View 18(2): 233-241.

Sekelj, Laslo (2001): Forced Democratization of a Criminalized State, in Spasić, Ivana - Subotić, Milan, eds., Revolution and Order: Serbia After October 2000, 95-108, Ifdt.

Spasojević, Dušan (2019): Riding the Wave of Distrust and Alienation-New Parties in Serbia After 2008. Politics in Central Europe 15(1): 139-162.

Spasojević, Dušan (2020): Rising Expectations and Centralizing Power: Party Leaders in Serbia, in Gherghina, Sergiu, ed., Party Leaders in Eastern Europe, 219-240, Palgrave Macmillan.

Steele, Brent J. - Homolar, Alexandra (2019): Ontological Insecurities and the Politics of Contemporary Populism. Cambridge Review of International Affairs 32(3): 214-221.

Stoecker, Randy (1995): Community, Movement, Organization: The Problem of Identity Convergence in Collective Action. Sociological Quarterly 36(1): 111-130.

Stojanović, Marija (2020): 'Izveštaji Evropske komisije o Srbiji i CG neće biti pozitivni', Danas (21 August): available at: https://www.danas.rs/drustvo/vladavina-prava/izvestaji-evropske-komisije-o-srbiji-i-cg-nece-biti-pozitivni/ (12 March 2021). 
Stojiljković, Zoran - Spasojević, Dušan (2018): Populistički Zeitgeist u 'Proevropskoj' Srbiji. Politička misao: časopis za politologiju 55(3): 104-128.

Subotić, Jelena (2012): The Past is Not Yet Over: Remembrance, Justice and Security Community in the Western Balkans. Journal of Regional Security 7(2): 107-118.

Svenonius, Ola - Bjorklund, Frederika (2018): Explaining Attitudes to Secret |Surveillance in Post-communist Societies. East European Politics 34(2): 123-151.

Szymański, Adam - Ufel, Wojciech (2018): Beyond Vote Rigging: Common Patterns in Electoral Malpractices in De-democratizing Regimes. Polish Political Science Yearbook 4: 593-617.

Tanjug (2017a): 'SNS: Ogoljena politika mržnje Boška Obradovića i Dveri', Blic (16 June): available at: https://www.blic.rs/vesti/politika/sns-ogoljena-politika-mrznje-boska-obradovica-i-dveri/ nmlkxt1 (19 March 2021).

Tanjug (2017b): ‘Obradović doneo ikebanu: Brnabić je projekat Tonija Blera o koordinatoru', Blic (28 June): available at: https://www.blic.rs/vesti/politika/obradovic-doneo-ikebanu-brnabic-je-projekat-tonija-blera-o-koordinatoru/qjzvj87 (19 March 2021).

Tanjug (2019): 'Ivica Dačić: Nisam ni ruski ni američki čovek, radim samo za Srbiju', Novosti (8 September): available at: https://www.novosti.rs/vesti/naslovna/politika/aktuelno.289. html:817014-Ivica-Dacic-Nisam-ni-ruski-ni-americki-covek-radim-samo-za-Srbiju (31 March 2021).

Tournois, Laurent (2021): Pandemopolitics' in Serbia: The Resurgence of Nationalism? Political Geography: available at: https://doi.org/10.1016/j.polgeo.2021.102375.

Trivić, Branka (2018): 'Veber: Od razmene teritorija nema ništa, jer je Berlin protiv', Radio Slobodna Evropa (10 August): available at: https://www.slobodnaevropa.org/a/srbija-nemacka-rusija-eu/29426309.html (29 March 2021).

Valtner, Lidija (2021): 'Miša Vacić je ipak Vučićev projekat', Danas (12 March): available at https:// www.danas.rs/politika/misa-vacic-je-ipak-Vučicev-projekat/ (31 March 2021).

Vladisavljević, Nebojša (2016): Competitive Authoritarianism and Popular Protest: Evidence From Serbia Under Milošević. International Political Science Review 37(1): 36-50.

Vlaisavljević, Ugo (2007): Rat Kao Najveći Kulturni Događaj: Ka Semiotici Etnonacionalizma, Meuna-fe 1950 Publishing.

Vračić, Alida (2018): The Way Back: Brain Drain and Prosperity in the Western Balkans, European Council on Foreign Relations (9 May): available at: https://ecfr.eu/publication/the_way_back_ brain_drain_and_prosperity_in_the_western_balkans/ (23 March 2021).

Vujačić, Veljko (2007): Elites, Narratives, and Nationalist Mobilization in the Former Yugoslavia. Comparative Politics 40(1): 103-124.

Wedeen, Lisa (2010): Reflections on Ethnographic Work in Political Science. Annual Review of Political Science 13: 255-272.

Yanow, Dvora (2007): Interpretation in Policy Analysis: On Methods and Practice. Critical policy analysis 1(1): 110-122.

Zakaria, Fareed (1997): The Rise of Illiberal Democracy. Foreign Affairs 76: 22-43. 
Zulianello, Mattia (2020): Varieties of Populist Parties and Party Systems in Europe: From State-of-the-art to the Application of a Novel Classification Scheme to 66 Parties in 33 Countries. Government and Opposition 55(2): 327-347.

Laurent Tournois holds a, Ph.D. in Management Sciences from the Conservatoire National des Arts et Métiers de Paris. Previously, he was Head of marking department at ESSCA Paris-Angers (AACSB accredited), DBA Program Director at Grenoble Ecole de Management (Triple Crown accredited) and Director of Business Graduate Studies at University of Dubai (AACSB accredited). Currently, he is, Ph.D. candidate in Political Science at Université Côte d'Azur. His doctoral work is dealing with the relationships between politics, cultural representations and top/down identity building strategies in the Balkans, with a specific focus on Serbia. He has published in journals such as Political Geography, Cities, Current Issues in Tourism and Tourism Management among others. He speaks fluently and writes Serbian. Email: laurent. tournoisbg@gmail.com or laurent.tournois@etu.univ-cotedazur.fr. 